Amer. J. Bot. 63(7): 919-924. 1976.

\title{
GAMETOPHYTES AND SUBGENERIC CONCEPTS IN LYCOPODIUM ${ }^{1}$
}

\author{
JAMES G. BRUCE \\ Department of Botany, University of Michigan, Ann Arbor 48109
}

A B S T R A C T

A critique of the Freeberg and Wetmore work on cultured Lycopodium gametophytes of $L$. selago, L. flabelliforme, and L. cernuum is presented. All three gametophytes are shown actually to be $L$. cernuum based on morphological and anatomical features of their sporophytes. A reassessment of characters in the genus demonstrates the taxonomic validity of the three groups proposed as subgenera within Lycopodium.

CONSIDERABLE DISAGREEMENT has been generated over the generic taxonomy of Lycopodium, the clubmosses. A number of separate genera have been proposed even within the last twenty years (Holub, 1964; Vasconcellos and Franco, 1967). Other authors have argued forcefully for the traditional maintainance of a single genus (Wilce, 1972), and the situation is still fluid.

One of the more important pieces of taxonomic evidence has been the remarkable diversity of form discovered in the gametophytes of Lycopodium. Bruchmann (1898), in his monumental study of Lycopodium gametophytes, erected five categories based on the diversity of types found by him and others. The various types are represented by particular species, L. clavatum (Type 1), L. complanatum (Type 2), L. selago (Type 3 ), L. inundatum (Type 4), and L. phlegmaria (Type 5). Bruchmann (1898) further proposed that five genera be named to correspond with this diversity, but he did not name these. Unfortunately, only a few species of Lycopodium are known from their gametophytes so that an assignment to a taxonomic unit based solely upon the type of gametophyte is impractical. However, it is interesting to note that all gametophytes described since Bruchmann's (1898) work have in fact fitted into one or the other of his categories.

Later workers (Rothmaler, 1944; Boivin, 1950) found the different gametophytic types to be taxonomically useful. In fact, Rothmaler (1944) used them in part in his recognition of four genera, Lycopodium (Type 1 gametophyte), Diphasium (Type 2), Lepidotis (Lycopodiella) (Type 4), and Huperzia (Types 3, 5), and this treatment was later adopted in the Flora Europaea.

However, the gametophytic evidence was called into question by subsequent laboratory studies. The remarkable report by Freeberg and Wetmore (1957) that gametophytes of certain Lycopodium

\footnotetext{
${ }^{1}$ Received for publication 23 July 1975.

I thank Dr. Warren $H$. Wagner and Dr. Michael R. Mesler for their help and criticisms of this work.
}

species, when grown under identical cultural conditions, became strikingly similar to each other has been particularly disquieting. They purportedly found that in the absence of any associated endophytic fungi the cultured gametophytes of what they designated as " $L$. complanatum var. flabelliforme" and "L. selago" were surficial, photosynthetic, and morphologically almost indistinguishable from both the wild and cultured gametophytes of $L$. cernuum. This fact has been used to suggest that gametophytic form is simply a consequence of growth conditions, and that the remarkable diversity of form is therefore of little systematic value. As Wagner (1974) points out, "If the distinctive gametophytes of two lycopod 'genera' can be grown artificially under conditions that make them develop into the gametophytetype of a third 'genus,' then one may well question the value of the gametophyte in the taxonomy of clubmosses."

Recently Whittier (1975) studied the gametophytes of Lyocopdium obscurum. He was successful in culturing these saprophytic gametophytes in a medium free of their endophytic fungi. These gametophytes, however, retained their normal morphology in spite of absence of the fungi. He placed some of the cultures in the dark and others in the light. Only the spores in culture which were kept in the dark germinated and produced gametophytes. Upon exposure to light the gametophytes, which were initially cultured in the dark, became pale green after several months. No concomitant change in morphology was reported. The largest gametophyte grown by Whittier was reasonably typical of wild $L$. obscurum as it possessed a thickened, disk shape. Although Whittier's work (1975) does not test directly the conclusions of Freeberg and Wetmore (1957) and Freeberg (1957), his findings suggest strongly the need to reevaluate their findings.

Several features of the Freeberg-Wetmore work are quite unexpected, and I list these below. (Lycopodium taxonomy adopted here is based on 


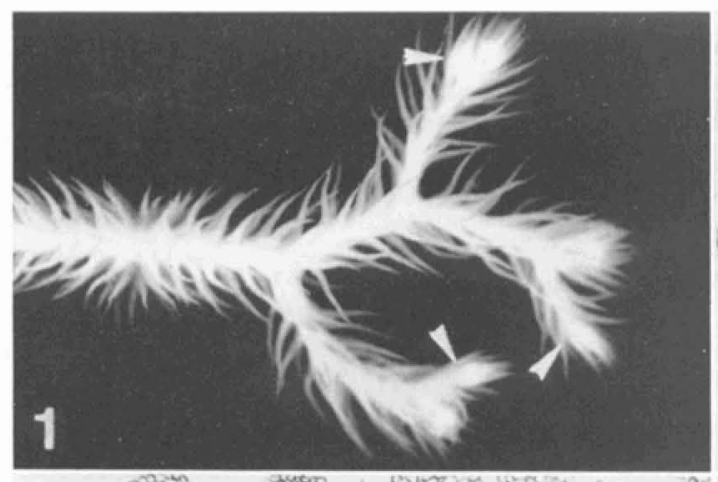

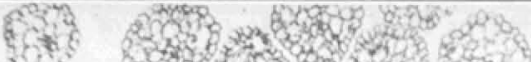

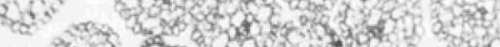

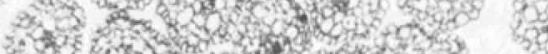

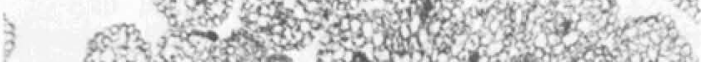
s.t.

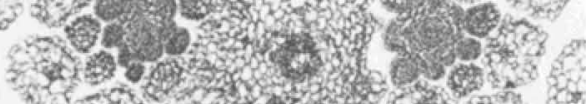
Whis

2 .

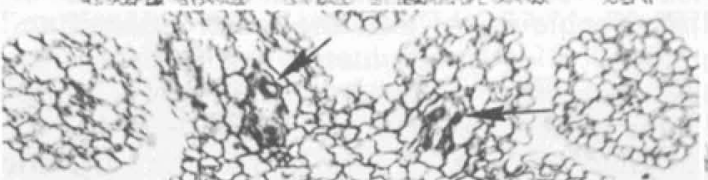

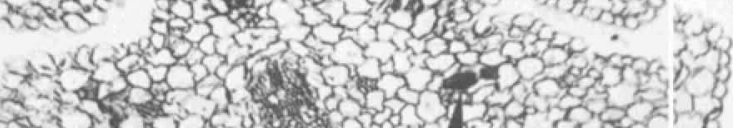

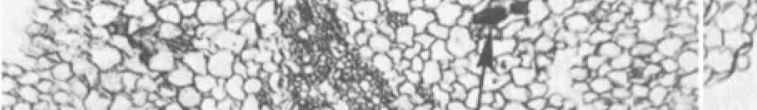

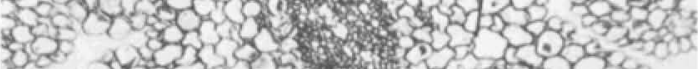

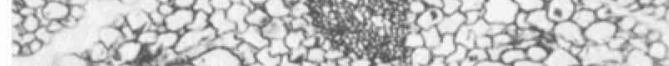
B. Bर Dtac 7332 sर

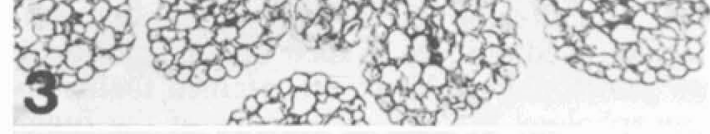

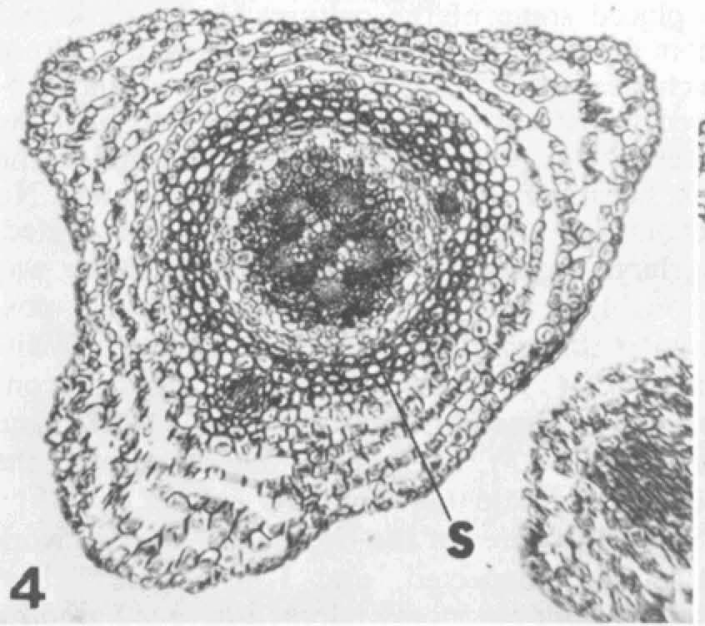

\section{6}

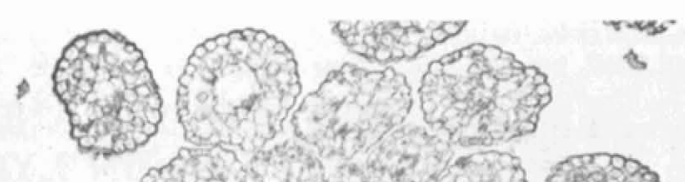

W3.

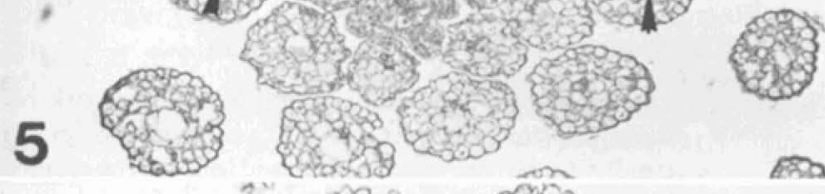

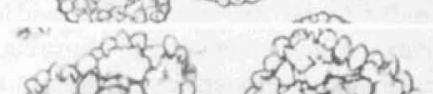

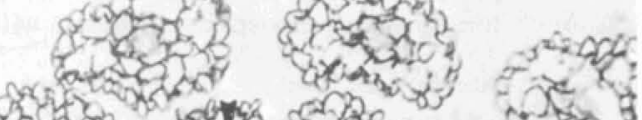
(5)

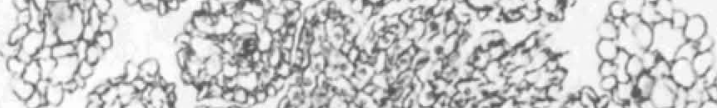

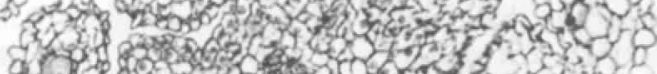

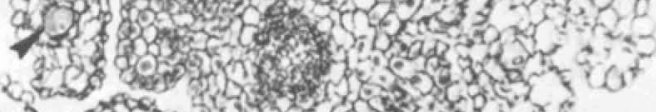
3.

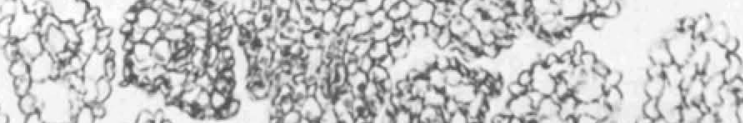

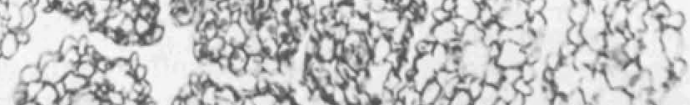
की

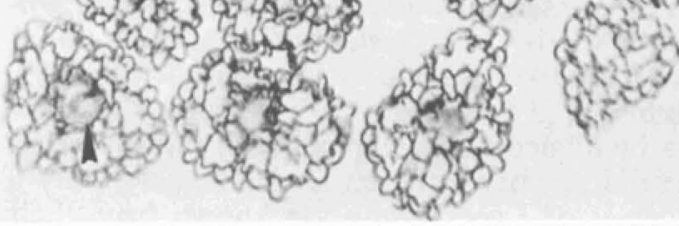

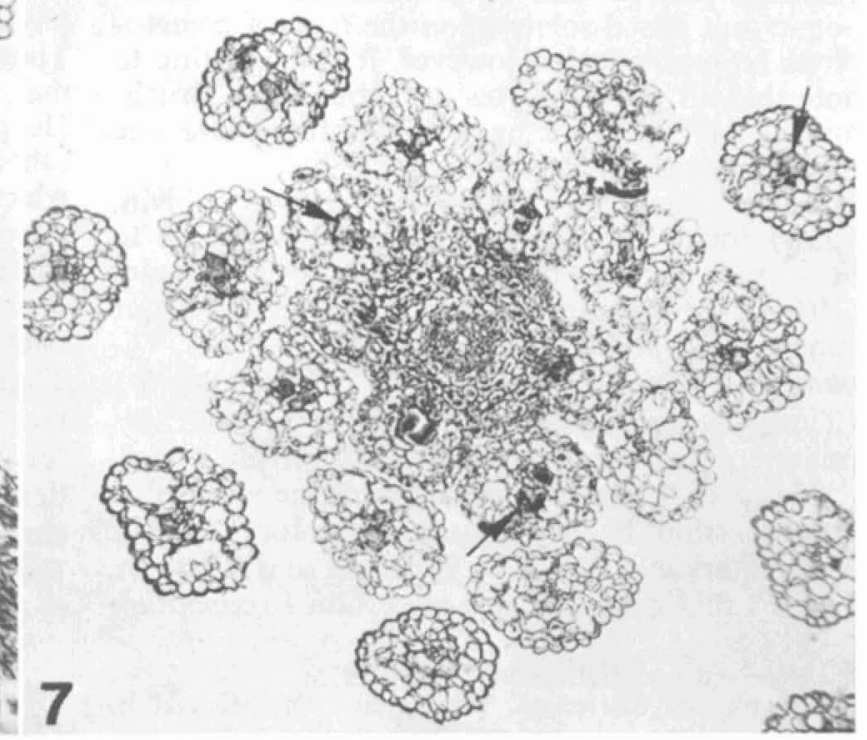


Wilce, 1972, viz., subgenus Lycopodium including $L$. complanatum var. flabelliforme, referred to as $L$. flabelliforme below, subgenus Lepidotis including $L$. cernuum, and sugenus Urostachys including $L$. selago.)

\section{GAMETOPHYTE}

1. The general organography of the reported cultured gametophytes of both $L$. selago and $L$. flabelliforme is similar to both cultured and wild $L$. cernuum, but is different from wild $L$. selago (Bruchmann, 1898) and wild L. flabelliforme. ${ }^{1}$ The overall form as well as the production of multicellular lobes in and around where the sex organs are produced is quite like the situation found in $L$. cernuum as described by Treub (1884).

2. L. selago may be green and surficial in the wild condition as shown by Bruchmann (1898) and, when it is, it does not produce the distinctive multicellular lobes reported in the cultured material.

3. The well-defined meristem present in the wild gametophytes of $L$. selago and $L$. flabelliforme is absent in the cultured specimens of these two species. $L$. cernuum lacks such a meristem in the wild state as well as in culture.

4. Short-necked archegonia are characteristic of subgenus Lepidotis which includes $L$. cernuum. The details of the presumed $L$. flabelliforme archegonium (Freeberg and Wetmore, 1957) show the outer tiers of neck cells sloughed off. This condition is similar to the condition described for $L$. cernuum (Treub, 1884) and L. inundatum (Goebel, 1887; Bruce, 1972). Indeed, the resemblance is strengthened by the presence of thickening in the walls of the lower tier of neck cells apparent in the photograph of the presumed

\footnotetext{
${ }^{1}$ Structural details of the wild gametophytes of $L$. flabelliforme have not been described in the literature. The gametophytes are, however, similar to those described for the very closely related and often synonymized L. complanatum. Indeed, Wilce (1965) has suggested that some descriptions of gametophytes may have been erroneously attributed to $L$. complanatum and may actually be L. flabelliforme or L. tristachyum. One specimen from Massachusetts, which I have examined, is very probably $L$. flabelliforme because it was associated with a colony of $L$. flabelliforme; L. tristachyum was not in that area, and, as Wilce (1965) states, L. complanatum is unknown from Massachusetts.
}

L. flabelliforme archegonium. This is pointed out specifically by Treub (1884) for L. cernuum, and this condition can also be observed in $L$. inundatum (Bruce, 1972). It is not known, however, to occur in L. selago or in any of the described materials of $L$. complanatum.

5. Freeberg and Wetmore (1957) did not note the occurrence of multicellular, uniseriate paraphyses in cultured $L$. selago. These structuresunknown in other lycopods-are diagnostic for all known gametophytes of subgenus Urostachys, which includes $L$. selago.

\section{SPOROPHYTE}

1. The aciculate leaves of all three cultivated taxa are closely similar to wild $L$. cernuum and unlike the juvenile leaves of $L$. selago and $L$. flabelliforme, both of which have flatter, more blade-like laminae.

2. Young sporophytes of what was identified as L. flabelliforme, even when they were maintained in culture for a considerable period of time, never developed the reduced leaves characteristic of wild sporophytes.

3. In Freeberg's (1957) interpretation both $L$. selago and $L$. flabelliforme were believed to produce conspicuous protocorms in culture. Such embryonic structures as far as we know are restricted, however, to the subgenus Lepidotis in the wild state and, except for a reference to a "reduced protocorm" in L. phlegmaria by Treub (1886), they are unknown in subgenus Urostachys or subgenus Lycopodium. Even in L. phlegmaria, however, the situation was exceptional, and may have represented simply an anomaly.

Freeberg and Wetmore (1957) and Freeberg (1957) interpreted most of these unexpected results as consequences of the absence of the endophytic fungi and growth of the gametophytes in light. I would like to suggest an alternative hypothesis which can account for the observed changes in a more parsimonious manner. Simply stated, my conclusion is that all materials successfully cultured by Freeberg and Wetmore were actually L. cernuum." This obviates the elaborate explana-

\footnotetext{
"Freeberg and Wetmore (1957) also cultured L. obscurum but the gametophytes did not grow beyond two or three millimeters in size and no sex organs were produced.
} $\leftarrow$

Fig. 1-7. 1. Young sporophyte of cultured L. "selago" which shows anisodichotomous branching (arrows). $\times 4$. 2. Transection of cultured $L$. "selago" which illustrates two anisodichotomous branches (densely stained axes to the right and left of the main central axis). $\times 17$. 3. Transection of cultured L. "selago" which clearly shows mucilage canals in basal portions of leaves and outer stem cortex (arrows) $\times 30$. 4. Transection of first sporophytic axis of young, wild $L$. flabelliforme with conspicuous sclerenchymatous band $(\mathrm{S})$ and no veinal mucilage canals. $\times 32$. 5. Transection of mature branch of small, wild $L$. cernutum which shows veinal mucilage canals (arrows). Comparison of this figure with $2,3,6$, and 7 shows remarkable similarity between the three cultured "species" and wild $L$. cernuum. $\times 30$. 6. Transection of cultured $L$. cernuum, veinal canals (arrows) easily apparent. $\times 32$. 7. Transection of cultured L. "flabelliforme" which shows veinal mucilage canals (arrows). $\times 25$. 
tions required by the several seemingly extraordinary departures from wild-type morphology for the saprophytic species. Essentially all anomalous features of the cultured plants thought to be $L$. selago and $L$. flabelliforme are resolved by assuming that they are in fact actually $L$. cernuum.

Materials and METHods-Dr. Freeberg has been so kind as to supply sporophytic materials from his experiments of all three species and gametophytic materials of two species, $L$. flabelliforme and $L$. cernuum. These had been preserved in FPA and were sent in three separately labeled vials. Specimens were photographed, and portions of the sporophytes were embedded and sectioned using standard paraffin techniques. Additionally, juvenile sporophytes and gametophytes of both $L$. flabelliforme and $L$. lucidulum were obtained through the generosity of Dr. George J. Wilder, and Dr. Warren H. Wagner kindly provided juvenile sporophytic plants of $L$. cernuum.

REsults-Isodichotomous branching, in which the shoot divides into two equal axes, characterizes the subgenus Urostachys. This produces the very symmetrically forked plants of $L$. selago and its relatives. Anisodichotomous branching, where one of the two branch shoots overtops the other, is restricted to subgenus Lepidotis and subgenus Lycopodium. However, in the photograph of one of the sporophytes of $L$. "selago" from culture, anisodichtomous branching can be seen (Fig. 1). In addition, in the sectioned material of cultured L. "selago" two anisodichotomous branchings are immediately apparent (Fig. 2).

In the course of studying certain anatomical features of Lycopodium, mucilage canals of two distinct types were found in various members of the genus (Bruce, 1976). One type, the basal canal, is restricted to the strobilus where it occurs in the sporophylls and outer cortex of the strobilar axis. This type is found in both subgenus Lepidotis and subgenus Lycopodium. The other type, the veinal canal, occurs in both sporophylls and vegetative leaves where it lies adjacent to the abaxial side of the vein. This type is known only from subgenus Lepidotis. Subgenus Urostachys was found to lack any sort of mucilage canals.

Thus, the vegetative leaves of both subgenus Urostachys, which includes $L$. selago, and subgenus Lycopodium, which includes $L$. flabelliforme, lack mucilage canals. This finding meant that the alternative hypothesis of contamination bv $L$. cernuum in the Freeberg and Wetmore (1957) work could be tested directly.

All three of the cultured "species" were found to possess veinal mucilage canals associated with the vegetative leaves (Fig. 3, 6, 7). This is a characteristic of the sporophytes in subgenus Lepidotis which includes L. cernuum. I have also examined wild materials of mature $L$. selago as well as juvenile wild materials of $L$. lucidulum, a close relative of $L$. selago, and found no mucilage canals. Additionally, juvenile wild materials of $L$. cernuum possess conspicuous mucilage canals. Finally, juvenile wild material of $L$. flabelliforme showed no mucilage canals (Fig. 4).

Examination of the juvenile wild plant of $L$. flabelliforme from Massachusetts shows a conspicuous sclerenchymatous band in cross-section (Fig. 4). This band lies just outside of the stele much as is found in mature plants of $L$. flabelliforme (Roberts and Herty, 1934). This band is absent from the cultured L. "flabelliforme" (Fig. 7). Comparison of the sections of the three cultured "species" (Fig. 3, 6, 7) with a section of a smaller branch of wild mature L. cernuum (Fig. 5 ), however, reveals that the three cultured "species" are indistinguishable from the wild $L$. cernuum.

Discussion-The present information concerning both histological features and branching characters of the sporophytes, combined with the points raised earlier, strongly suggests contamination of the $L$. selago and $L$. flabelliforme cultures with the spores of $L$. cernuum. The possibility of a contaminant other than $L$. cernuum was considered highly improbable because the cultured $L$. cernuum attained reproductive maturity and the other two species closely resembled it.

It is still possible that Lycopodium gametophytes may extensively alter their morphology in the absence of their endophytic fungi or when grown under unusual light regimes. However, this is not yet demonstrated to be the case, as the basis for this conclusion is shown to be untenable. Unless future work contradicts this the gametophyte continues, therefore, to be a valuable source of systematic data in formulating the taxonomy of Lycopodium. It can no longer be assumed that the form of a gametophyte is simply an ecological manifestation resulting from the level to which its spore is dispersed in the soil prior to germination (Freeberg and Wetmore, 1957).

With this in mind, the number of features of value in delimiting groups in Lycopodium is considerably increased. Rothmaler (1944), Chowdhury (1937), Boivin (1950), Wilce (1972), $\varnothing$ llgaard (1975), Bruce (1976), among others, have contributed useful information. This and other information is summarized in Table 1. Some of these features are based on very few species and may require future revision. These data, in my opinion, warrant the recognition of these three subgenera of Lycopodium. All are distinct, although subgenus Lepidotis and subgenus Lycopodium are more similar to each other than either is to the subgenus Urostachys. The characters involved are both sporophytic and gametophytic and include features of both vegetative and reproductive organs. In fact, nearly every aspect of the 
TABLE 1. Summary of subgeneric characteristics in Lycopodium

\begin{tabular}{|c|c|c|c|}
\hline Character & Subg. Lycopodium & Subg. Lepidotis & Subg. Urostachys \\
\hline \multicolumn{4}{|l|}{ SPOROPHYTE } \\
\hline Major branching & Anisodichotomous & Anisodichotomous & Isodichotomous \\
\hline Shoot type & $\begin{array}{l}\text { Horizontal indeterminate } \\
\text { and upright determinate }\end{array}$ & $\begin{array}{l}\text { Horizontal indeterminate } \\
\text { and upright determinate }\end{array}$ & $\begin{array}{l}\text { Either all indeterminate or } \\
\text { all determinate }\end{array}$ \\
\hline Root emergence & Direct & Direct & Long, descending in cortex \\
\hline Root stele at origin & Polyarch & C-shaped & C-shaped \\
\hline Root hair initial division & Oblique & Straight? & Oblique \\
\hline $\begin{array}{l}\text { Sporophyll blade attach- } \\
\text { ment }^{\mathrm{a}}\end{array}$ & Pseudopeltate & Pseudopeltate & Sessile or nearly so \\
\hline Sporophyll stalk & Present & Present & Absent or nearly so \\
\hline Sporangial stalk & Thick & Thick & Thin? \\
\hline Sporangial position & On sporophyll stalk & $\begin{array}{l}\text { Axillary or on sporophyll } \\
\text { stalk }\end{array}$ & Axillary \\
\hline $\begin{array}{l}\text { Sinuosity of side walls of } \\
\text { sporangial cells. }\end{array}$ & Sinuate & Straight & Sinuate \\
\hline $\begin{array}{l}\text { Thickness of side walls of } \\
\text { sporangial cells }\end{array}$ & Thin & Thin & Thick \\
\hline $\begin{array}{l}\text { Lignification of side walls } \\
\text { of sporangial cells }\end{array}$ & Lignified & Unlignified & Lignified \\
\hline Veinal mucilage canals & Absent & Present or absent & Absent \\
\hline Basal mucilage canals ${ }^{\mathbf{a}}$ & Present & Present & Absent \\
\hline \multicolumn{4}{|l|}{ GAMETOPHYTE } \\
\hline Shape & $\begin{array}{l}\text { Carrot or convoluted } \\
\text { button }\end{array}$ & $\begin{array}{l}\text { Tuberous with multicel- } \\
\text { lular lobes }\end{array}$ & $\begin{array}{l}\text { Cylindrical with radial or bi- } \\
\text { lateral symmetry }\end{array}$ \\
\hline Nutrition & Holosaprophytic & Hemisaprophytic & Holosaprophytic \\
\hline Position in substrate & Below surface & Surficial & Below surface \\
\hline Archegonial length & Long & Short & Long \\
\hline $\begin{array}{l}\text { Archegonial neck longevity } \\
\text { Wall of basal tier of neck }\end{array}$ & Persistent & Ephemeral & Persistent \\
\hline cells & Thin & Thick & Thin \\
\hline Paraphyses & Absent & Absent & Present \\
\hline \multicolumn{4}{|l|}{ CHROMOSOMES } \\
\hline Number & $x=23,34$ & $x=35,78$ & $x=? 44,45$ \\
\hline \multicolumn{4}{|l|}{ SPORES } \\
\hline Surface ornamentation & Reticulate & Rugulate & Foveolate-fossulate \\
\hline
\end{tabular}

"The pseudopeltate condition of the sporophyll and the basal mucilage canal are probably different expressions of the same character (Bruce, 1976).

life cycle is taxonomically important. It is interesting in this regard to draw attention to the discussion by Sneath and Sokal (1973) of classifications based on different portions of life cycles of organisms. They have suggested that similarity or congruence between classifications of this sort will be greater the higher the rank of the taxa involved. In Lycopodium, where a broad array of characters from each of the stages of the life cycle supports the division of the genus into three units, a taxonomic elevation of the subgenera to generic rank would appear reasonable. However, Wilce (1972, p. 79) has argued strongly for the main- tainence of a single genus based largely on the ease with which the group is recognized as "a relatively non-arbitrary clustering of related elements." This, perhaps, is the best and most practical approach at present, not only for the reasons given, but also because of the considerable amount of new information of taxonomic importance in Lycopodium which has become available only recently. Much of this information will need to be digested and evaluated in order to arrive at a consensus. Taxonomic arguments have the peculiar distinction in science in that they are based in part on judgement and tradition, and an opinion which 
reflects thoughtful consideration of both the facts and historical perspective is the one most likely to survive.

\section{LITERATURE CITED}

Borvin, B. 1950. The problem of generic segregates in the form-genus Lycopodium. Amer. Fern J. 40: $32-41$.

BRUCE, J. G. 1972. Observations on the occurrence of the prothallia of Lypodium inundatum. Amer. Fern J. 82-87.

- 1976. Development and distribution of mucilage canals in Lycopodium. Amer. J. Bot. 63: $481-491$.

BruchmanN, H. 1898. Über die Prothallien und die Keimpflanzen mehrerer europäischer Lycopodien. Gotha.

Chowdhury, N. P. 1937. Notes on some Indian species of Lycopodium with remarks on the distribution of the genus in India. Trans. Nat. Inst. Sci. India 1: $187-226$.

FreeberG, J. A. 1957. The apogamous development of sporelings of Lycopodium cernuum L., L. complanatum var. flabelliforme Fernald and $L$. selago L. in vitro. Phytomorphology 7: 217-229. , AND R. H. WETMORE. 1957. Gametophytes of Lycopodium as grown in vitro. Phytomorphology 7: 204-217.

Goebel, K. 1887. Ueber Prothallien und Keimpflanzen von Lycopodium inundatum. Bot. Zeit. 45: $161-168,177-190$.

Holub, J. 1964. Lycopodiella, nový rod řádu Lycopodiales. Preslia 36: 16-22. $\emptyset_{\text {LlgaARD, B. }}$ 1975. Studies in Lycopodiaceae, I. Observations on the structure of the sporangium wall. Amer. Fern J. 65: 19-27.

Roberts, E. A., AND S. D. Herty. 1934. Lycopodium complanatum var. flabelliforme Fernald: Its anatomy and method of vegetative reproduction. Amer. J. Bot. 21: 688-697.

Rothmaler, W. 1944. Pteridophyten-Studien I. Feddes Repert. Spec. Nov. Regni Veg. 54: 55-82.

SNeATH, P. H. A., AND R. R. SoKal. 1973. Numerical taxonomy. W. H. Freeman and Co., San Francisco.

Treub, M. 1884. Études sur les Lycopodiacées. I. Le prothalle du Lycopodium cernuum L. Ann. Jard. Bot. Buitenzorg 4: 107-138.

—. 1886. Études sur les Lycopodiacées. III. Le developpement de l'embryon chez le Lycopodium phlegmaria L. Ann. Jard. Bot. Buitenzorg 5: 115 139.

Vasconcellos, J. de C., and J. do A. Franco. 1967. Breves notas sobre Licopodiáceas. Bol. Soc. Broteriana 41 (sér. 2) : 23-25.

Wagner, W. H. 1974. Pteridology 1947-1972. Ann. Mo. Bot. Gard. 61: 86-111.

Whittier, D. P. 1975. The growth of gametophytes of Lycopodium obscurum in axenic culture. Bot. Soc. Amer., abstracts of papers presented at Oregon State University, Corvallis, 17-22 August 1975, p. 41.

Wilce, J. H. 1965. Section Complanata of the genus Lycopodium. Nova Hedwigia 19: 1-233.

- 1972. Lycopod spores, I. General spore patterns and the generic segregates of Lycopodium. Amer. Fern J. 62: 65-79. 